\title{
Agentes de Segurança Pública e suas (Des) Identidades
}

\author{
Matusalém Ferreira da Silva Júnior
}

\section{Resumo}

Um quebra-cabeça, ilustrando, já pressupõe uma imagem final, onde existe apenas o trabalho de unir as peças que também foram elaboradas de acordo com essa imagem fim, na identidade o sujeito precisa unir peças de várias imagens diferentes, por vezes conflitantes, e nunca possuirá um resultado unificado e coeso. Outra grande diferença entre o brinquedo e a construção identitária é que, no primeiro, todas as peças do jogo estão presentes, não há lacuna, nada está sobrando, tudo já está preestabelecido, se algo faltar, volta à loja e devolve o brinquedo, usando o argumento de que ele está incompleto e, por isso não serve para brincar. Enquanto no jogo a tarefa é "direcionada para o objetivo" (montar uma imagem pronta), no caso da identidade, o trabalho é "direcionado para os meios" (BAUMAN, 2005, p. 55).

BAUMAN (2005) ainda exemplifica essa montagem da identidade a partir de um slong publicitário espalhado pelas ruas de Berlim em 1994. Neste texto, o sujeito é descrito pelos bens consumidos que são expressões de diversas culturas do mundo. "Seu Cristo é judeu. Seu carro é japonês. Sua pizza é italiana. Sua democracia, grega. Seu café, brasileiro. Seu feriado, turco. Seus algarismos, arábicos. Suas letras, latinas. Só o seu vizinho é estrangeiro" (BAUMAN, 2005, p. 32).

Essa problemática, acrescenta, é um fenômeno recente, para ser mais exato da era da globalização. E isso basicamente por dois motivos: as novas tecnologias da informação e a perda da intimidade em virtude dessas 
tecnologias. Ao apontar o surgimento da identidade como um problema na era do pós-guerra, Bauman dialoga com importantes pensadores contemporâneos, como Stuart Hall para quem também a globalização seria o processo sintetizador da mudança de postura do homem em relação a sua identidade. "Globalização significa que o Estado não tem mais o poder ou o desejo de manter uma união sólida e inabalável com a nação" (BAUMAN, 2005, p. 34).

Assim como Bauman, Hall defende que uma das principais alterações provocadas por esse processo seria a "compressão do espaço-tempo", uma espécie de a "aceleração dos processos globais, de forma que se sente que o mundo é menor que as distâncias mais curtas, que os eventos em um determinado lugar têm um impacto imediato sobre pessoas e lugares situados a uma grande distância” (HALL, 1999, p. 69).

O mito da verdade real, de cunho nitidamente autoritário, esmoreceu diante dos postulados e garantias impostas de maneira legal pelo Estado de direito. As limitações decorrentes dos devidos processos legais e das garantias dele decorrentes (inadmissibilidade da prova ilícita, ampla defesa, contraditório, direito ao silencio, a não ser obrigado a produzir prova contra si mesmo entre outros) demonstram que a verdade processual é somente e tão somente aquela possível, atingível nos estreitos limites da legalidade. Pelo ordenamento jurídico brasileiro cabe à Polícia Judiciária (Civil) a apuração preliminar das infrações e de sua autoria, com a identificação do ato delituoso e se possível do autor, sendo certo que o resultado servirá de sustentação a uma possível ação, seja ela penal ou não.

Esta conduta tem tratamento extrajudicial, é de suma importância na formação do livre convencimento do Juiz e nas decisões por ele tomada principalmente no final julgamento da causa. O mesmo se aplica ao DD Representante do Ministério Público, pois suas ações relacionadas ao fato só 
ocorrerão após minuciosas considerações e análise de provas até então apresentadas colidas, extrajudicalmente, por um profissional de Segurança Pública.

Eis a importância da conduta do Profissional de Segurança Pública, bem como sua postura, seus apontamentos, a descrição dos fatos, identificação do local de crime e a valorização das provas apresentadas a autoridade competente.

A dúvida que paira e motiva nossa pesquisa é a de que os Profissionais de Segurança Pública, não só os que estão investidos da função constitucional da preservação e constituição da prova, mas todos eles, Militares, Civis, Militares Bombeiros, Policiais Ferroviários, Rodoviários e Guardas Municipais tem a exata dimensão de suas responsabilidades e sabem fazer uso das tecnologias da Informação que lhes são disponibilizadas, eles mudaram suas condutas em virtude da disponibilização destas novas ferramentas? E a adoção desta nova postura mudou sua identidade?

Hodiernamente temos a dicotomia em relação a definição de identidade, pode ela ser flexível ou deve ser imutável, e esta discussão, estes conflitos de ideologia a respeito da identidade tem como um dos pontos fundamentais o avanço da tecnologia, A partir do surgimento de dispositivos tecnológicos, como a fotocopiadora, a filmadora portátil, o telefone celular, que não podem ser considerados cultos ou populares, as referências semânticas que ancoravam o sentido da identidade nacional são questionadas e colocadas em cheque.

Muito embora a incumbência funcional da busca de provas (penal) seja atribuída à Polícia Judiciária não se pode perder a proposta política embutida no texto Constitucional quanto à complementaridade das ações de Segurança Pública. Esse princípio respalda o sistema brasileiro que não contempla a existência de polícia com ciclo completo de ações e sendo 
assim, a Segurança Pública é uma estrutura de cooperação. A Matriz Curricular para a Formação de Profissionais na Área de Segurança Pública respalda a prática. O local de crime é um local especial, pois é nele que as provas são mais evidentes, a regra é que as Polícias Militar e Civil atuem conjuntamente. Aquela, chegando primeiro ao local de crime, tomando as primeiras providências no que insurge os cuidados iniciais com a preservação do local de crime preservando as provas, materiais e especialmente subjetivas. Em alguns casos, além dessas organizações, também participam dessa tomada de decisão inicial, o Corpo de Bombeiros, o Departamento de trânsito ou Guarda Municipal. Será que a atitude desses agentes é a mesma de tempos atrás estando os mesmos cientes de que o local de crime pode estar sendo monitorado? Toda a investigação deverá ser conduzida no intuito de verificarmos a ocorrência da (des) identidade dos agentes de segurança pública em relação a disponibilização de novas ferramentas de trabalho e se a possibilidade de estar sendo "visto" por algum meio de tecnologia muda suas forma de atuação.

Discurso é uma forma de apreensão da linguagem, não sendo considerado como uma estrutura arbitrária, mas como atividade de sujeitos inscritos em contextos determinados. Nesse caso, o discurso não pode ser objeto de uma análise somente linguística. Portanto, o discurso é tanto um lugar privilegiado de observação das relações entre língua e ideologia, quanto um lugar de mediação; é a linguagem em funcionamento, é uma prática social contextualizada.

Com efeito, o discurso jurídico é tomado e (re)significado, sob novas condições de produção e as condições de possibilidades semânticas desse discurso se materializam num campo de troca, sem jamais encobrir a sua identidade. Por isso, toda formação discursiva só será definida, constituída e mantida a partir de sua relação com o interdiscurso, e este, por sua vez, 
consiste em um processo de reconstrução à formação discursiva, permitindo as possíveis inferências discursivas.

Em decorrência da natureza histórica determinada dos interlocutores no discurso (justiça), apresentaremos o processo da proposta metodológica e o funcionamento discursivo do corpus, escolhendo como ponto fundamental dessa abordagem a relação sujeito/sentido/discurso. Para tanto, analisaremos a interdiscursividade na constituição do discurso jurídico, objetivando apontar os possíveis efeitos de sentido produzidos por eles na aplicação e utilização das novas tecnologias.

Nos referimos, não só ao estrito cumprimento do dever legal, mas uma condição observada pelo agente que possa apresentar, a quem de direito (promotor, delegado, juiz) e que vá fazer a diferença no momento das tomadas das decisões e para tanto sabe ele, agente de segurança, utilizar de todas as novas possibilidades de exercício de sua função.

Devemos considerar o discurso como jogos estratégicos: de ação/reação, de pergunta/resposta, de coragem/inibição, de ataque/defesa, de saber/poder, e de conflito.

Palavras Chave: Identidade, Cultura, Construção da Identidade, Técnologias da Informação

\section{Referências}

BAKHTIN, M. Questões de Literatura e de Estética - a teoria do romance. Tradução Aurora Fornoni Bernadini et al. 4. ed. São Paulo: Editora UNESP, 1998 [1975]

CHARAUDEAU, P. MAINGUENEAU, D. Dicionário de análise do discurso. Tradução Fabiana Komesu (et al.) São Paulo: Contexto, 2004.

BAUMAN, Zygmunt. Identidade. Tradução de Carlos Alberto Medeiros. Rio de Janeiro: Jorge Zahar Editor, 2005. 
HALL, Stuart. A identidade cultural na pós-modernidade. Tradução de Tomaz Tadeu da Silva e Guacira Lopes Louro. $3^{\circ}$ ed. Rio de Janeiro: DPU\&A, 1999.

MATTELART, Armad. NEVEU, Érik. Introdução aos Estudos Culturais. São Paulo: Parábola, 2004. 